\title{
PReS-FINAL-2241: Cases of cryopyrin-associated periodic syndromes (CAPS) in one single rheumatologic center of Russia
}

\author{
SO Salugina ${ }^{*}$, E Fedorov $^{1}$, N Kuzmina ${ }^{1}$, E Zaharova $^{2}$ \\ From 20th Pediatric Rheumatology European Society (PReS) Congress \\ Ljubljana, Slovenia. 25-29 September 2013
}

\section{Introduction}

Cryopyrin-associated periodic syndromes (CAPS) are the rare hereditary autoinflammatory diseases. CAPS include three similar conditions are distinguished which lie along a phenotypical continuum with increasing levels of severity: familial cold autoinflammatory syndrome (FCAS), Muckle-Wells syndrome (MWS) and CINCA/ NOMID. Distinguishing features include cutaneous, neurological, ophthalmologic and rheumatologic manifestations. CAPS caused by the mutation of the NLRP3 (CIAS1) gene coding for cryopyrin.

\section{Objectives}

to investigate clinical and genetic characteristics of the pts with CAPS in single Federal rheumatologic center of Russia.

\section{Methods}

7 patients with CAPS were followed at our centre for 5 years since 2007. There are 3 boys, 4 girls, aged 2-16 years (mean 7,9 $\pm 5,2$ years) with disease's duration from 2 to 15 years. In 2 boys was diagnosed CINCA/ NOMID, 5 - MWS. All patients were submitted to routine rheumatology examination and laboratory parameters, genetic testing in all pts was performed in research centre for medical genetics in Moscow.

\section{Results}

Age of the first manifestation was from the birth to 9 years. All pts have had persistant or recurrent episodes fever, cutaneus rash (urticaria-like rash or maculo

\footnotetext{
${ }^{1}$ Children, Federal State Budgetary Institution "Research Institute of Rheumatology" under the Russian Academy of Medical Sciences, Moscow, Russian Federation

Full list of author information is available at the end of the article
}

papular). 5 of 7 pts have had ocular manifestations: 3- conjunctivitis, 4-uveitis. 2 - no ocular abnormalities. Sensoryneural hearing loss was diagnosed in 2 boys with CINCA/NOMID and in 2 girls with MWS. Joint involvement were observed in 6 of 7 (artralgias/non-destructive arthritis -5 , bone deformities - 1 and growth retardation in 2 boys with CINCA/NOMID). Central nervous system damage (hydrocephaly, atrophy on brain, mental retardation) was in 3 pts (2 - CINCA/ NOMID, 1- MWS). The laboratory findings included an elevation of acute phase reactants: ESR, neutrophil leukocytosis, C-reactive proteine rise, anemia. ANA and RF were negative. A genetic analysis on all pts showed a new mutations (heterozygous) in the NLRP3 gene: G569R, Met406Thr, Thr436Ile, Y441H, P350L, Thr438Ile, Gly455Term. No pts with AA amyloidosis and renal failure.

\section{Conclusion}

CAPS (CINCA/NOMID and MWS) are rare hereditary auto-inflammatory diseases but it can occur in Russia. CINCA/NOMID pts have the most serious clinical manifestations and prognosis. MWS pts more often have recurrent episodes fever, cutaneous rash, conjunctivitis. Pts with CAPS need early anti IL-1 treatment for the successful in suppressing inflammation, reduction in the number and duration attacks, for prevention of amyloidosis and improvement of life prognosis.

\section{Disclosure of interest}

None declared.
Authors' details

${ }^{1}$ Children, Federal State Budgetary Institution "Research Institute of

Rheumatology" under the Russian Academy of Medical Sciences, Moscow, 
Published: 5 December 2013

doi:10.1186/1546-0096-11-S2-P231

Cite this article as: Salugina et al:: PReS-FINAL-2241: Cases of cryopyrinassociated periodic syndromes (CAPS) in one single rheumatologic center of Russia. Pediatric Rheumatology 2013 11(Suppl 2):P231.

Submit your next manuscript to BioMed Central and take full advantage of:

- Convenient online submission

- Thorough peer review

- No space constraints or color figure charges

- Immediate publication on acceptance

- Inclusion in PubMed, CAS, Scopus and Google Scholar

- Research which is freely available for redistribution

Submit your manuscript at www.biomedcentral.com/submit
C Biomed Central 